\title{
GGE biplot analysis of multi-environment yield trials of rice produced in a temperate climate
}

\author{
Gabriel Donoso-Ñanculao ${ }^{1 *}$, Mario Paredes ${ }^{1}$, Viviana Becerra ${ }^{1}$, Camila Arrepol ${ }^{1}$,
} and Mónica Balzarini²

\section{ABSTRACT}

Low temperature is one of the main environmental constraints for rice (Oryza sativa L.) grain production yield. It is known that multi-environment studies play a critical role in the sustainability of rice production across diverse environments. However, there are few studies based on multi-environment studies of rice in temperate climates. The aim was to study the performance of rice plants in cold environments. Four experimental lines and six cultivars were evaluated at three locations during three seasons. The grain yield data were analyzed with ANOVA, mixed models based on the best linear unbiased predictors (BLUPs), and genotype plus Genotype $\times$ Environment interaction (GGE) biplot. High genotype contribution $(>25 \%)$ was observed in grain yield and the interaction between genotype and locations was not very important. Results also showed that 'Quila 241319' was the best experimental line with the highest grain yield $\left(11.3 \mathrm{t} \mathrm{ha}^{-1}\right)$ and grain yield stability across the environments; commercial cultivars were classified as medium grain yield genotypes.

Key words: BLUPs, GGE biplot, temperate rice, yield stability.

${ }^{1}$ Instituto de Investigaciones Agropecuarias, INIA Quilamapu, Av. Vicente Méndez 515, Chillán, Chile.

*Corresponding author (gabriel.donoso@inia.cl).

${ }^{2}$ Universidad Nacional de Córdoba, Facultad de Ciencias Agropecuarias, Avenida Enrique Barros esq. Los Nogales, Ciudad Universitaria, CP 5000, Córdoba, Argentina.

Received: 20 July 2015

Accepted: 15 November 2015.

doi:10.4067/S0718-58392016000200003

\section{INTRODUCTION}

Rice (Oryza sativa L.) is one of the principal foods worldwide and is subjected to an ever increasing demand that becomes harder to meet every year (Khush, 1997; Cantrell and Reeves, 2002). Raising world rice production by increasing sown areas is highly improbable, and the rice crisis scenario is a real problem (Khush, 1997). In addition, low temperatures are a main constraint for rice production in temperate climates (Sanghera et al., 2011; Zhang et al., 2014). It is therefore essential to apply new approaches to increase rice yield in already cultivated areas (Khush, 2005). The sustainability of rice production depends on the development of new rice cultivars with high yield and stable performance across diverse environments (Akter et al., 2014). Many tools related to grain yield analysis are available for this purpose. The best linear unbiased predictors (BLUPs) provide high accuracy of means estimation in contrast to other methodologies (Piepho et al., 2008). Genotype selection based on BLUPs has not been used much by plant breeders (Heffner et al., 2009). Another plant breeding strategy is the study of Genotype by Environment interaction (G $\times$ E) in multi-environment studies (Bose et al., 2013). The $G \times$ $\mathrm{E}$ interaction can cause differences in grain yield performance and stability of a genotype developed in different environments (Colombari Filho et al., 2013). The GGE biplot is a good tool to study $\mathrm{G} \times \mathrm{E}$ because it allows identifying genotypes with high grain yield and stability in different mega-environments (Karimizadeh et al., 2013). The GGE biplots allow for the analysis of many characteristics of genotypes and environments, such as finding the best performance genotype for each environment, genotype stability, representative environment, and discriminating power of each environment (Samonte et al., 2005).

The rice area in Chile where rice is cultivated is found in the southernmost zone. This area has a Mediterranean climate and includes the Maule and Biobío Regions, $35^{\circ}$ and $36^{\circ} \mathrm{S}$ lat, respectively (Donoso et al., 2014). Rice is cultivated between October and March in submerged soil with pre-germinated seeds (89\%) and dry soil with direct seeding (11\%) (ODEPA, 2013). Low temperatures are one of the main constraints of rice production in Chile. They can reduce grain yield by more than $40 \%$ (Alvarado and Hernaiz, 2007). Night temperatures are below $10^{\circ} \mathrm{C}$ at the vegetative stages and below $15^{\circ} \mathrm{C}$ during the reproductive stage (Alvarado and Hernaiz, 2007). The Chilean rice grain production from 2011 to 2013 only provided $60 \%$ of internal consumption while the remaining $40 \%$ was mainly imported from Argentina, Paraguay, Vietnam, and Uruguay (ODEPA, 2015). Therefore, increasing rice production in Chile to meet this $40 \%$ is possible by 
identifying new cultivars with high yield and stability across different environments.

For this reason, we proposed that the multi-environment study of rice genotypes from the Chilean Rice Breeding Program was an essential and easy tool to find "elite rice lines" with high grain yield performance and stability. Therefore, the aim of the present study was to find experimental lines with the best performance related to grain yield and quality across different environments.

\section{MATERIALS AND METHODS}

The experiment was conducted in three locations in Chile,

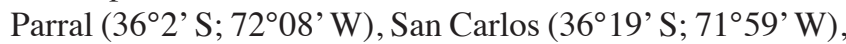
and Chillán $\left(36^{\circ} 35^{\prime} \mathrm{S} ; 72^{\circ} 5^{\prime} \mathrm{W}\right.$ ) during three seasons (20102011, 2011-2012, and 2012-2013). Temperature descriptions for all environments are shown in Figure 1. Soils were classified as Vertisol for Parral and Chillán and Inceptisol for

Figure 1. Seasonal temperatures during rice development in Chillán, San Carlos, and Parral for the a) 2010-2011, b) 20112012, and c) 2012-2013 seasons.

\section{a) Season 2010 - 2011}

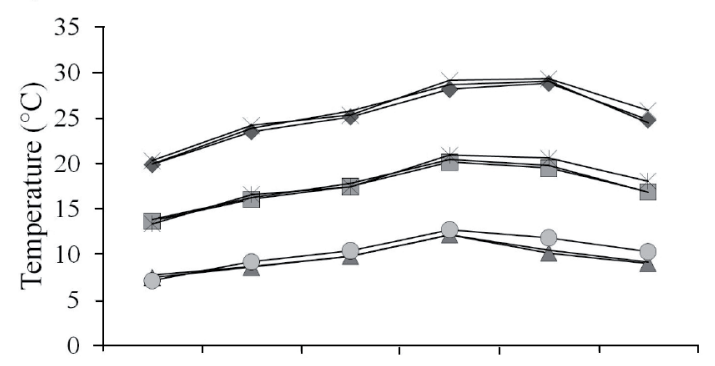

b) Season 2011 - 2012

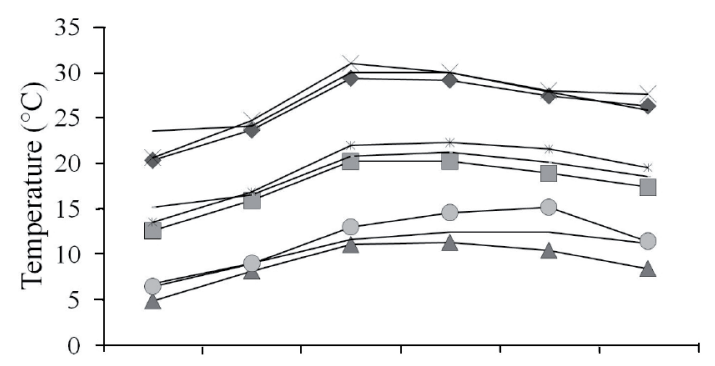

c) Season 2012 - 2013

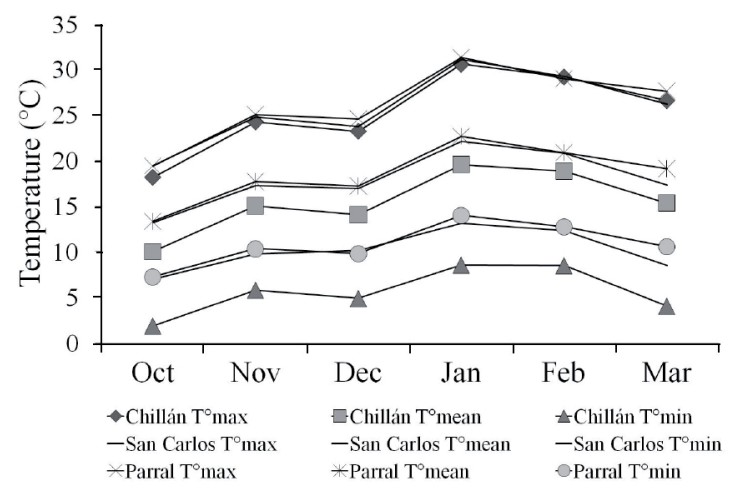

$\mathrm{T}^{\circ}$ max: maximum temperature, $\mathrm{T}^{\circ}$ mean: mean temperature, $\mathrm{T}^{\circ} \mathrm{min}$ minimum temperature.
Table 1. Grain shape of evaluated rice genotypes.

\begin{tabular}{|c|c|c|}
\hline $\mathrm{N}^{\circ}$ & Genotypes & Grain shape \\
\hline 1 & Ámbar-INIA † & Short \\
\hline 2 & Buli-INIA $\dagger$ & Long \\
\hline 3 & Cuarzo-INIA & Long \\
\hline 4 & Diamante-INIA $\dagger$ & Long \\
\hline 5 & $\mathrm{Oro}^{\dagger}$ & Short \\
\hline 6 & Quila $208902+\dagger$ & Long \\
\hline 7 & Quila $241319+\dagger$ & Medium \\
\hline 8 & Quila $242207+\dagger$ & Long \\
\hline 9 & RQuila $17+\dagger$ & Long \\
\hline 10 & Zafiro-INIA $\dagger$ & Long \\
\hline
\end{tabular}

†Cultivar.

$\dagger \dagger$ Experimental line.

San Carlos (Hirzel et al., 2011). Four experimental lines and six cultivars from the Chilean Rice Breeding Program were studied (Table 1). Before sowing, a chemical fallow with glyphosate $\left(0.96 \mathrm{~kg} \mathrm{ha}^{-1}\right)$ was applied. Seed rates were 140 $\mathrm{kg} \mathrm{ha}^{-1}$ in a $5 \times 2 \mathrm{~m}$ plot and sowing dates were between 10 to 15 October for all seasons and locations. Pre-germinated seeds were broadcast into the flooded plot at a $5 \mathrm{~cm}$ water depth. After the 3-4-leaf stage, water depth was increased to $10 \mathrm{~cm}$ and 15 to $20 \mathrm{~cm}$ at the reproductive stage. Later at the physiological maturity stage, water entry to the plot was stopped until harvest. Nitrogen was applied as urea at sowing $\left(88 \mathrm{~kg} \mathrm{ha}^{-1}\right)$, tillering stage $\left(88 \mathrm{~kg} \mathrm{ha}^{-1}\right)$, and booting stage $\left(66 \mathrm{~kg} \mathrm{ha}^{-1}\right)$. Potassium (140 kg K2 $\left.\mathrm{O} \mathrm{ha}^{-1}\right)$ and $\mathrm{P}\left(130 \mathrm{~kg} \mathrm{P}_{2} \mathrm{O}_{5} \mathrm{ha}^{-1}\right)$ were applied after sowing. For weed control, penoxsulam (48 $\mathrm{g} \mathrm{ha}^{-1}$; Ricer, Dow AgroSciences, Santa Fe, Argentina) was applied when rice had two or three leaves, and bentazone $\left(1.1 \mathrm{~kg} \mathrm{ha}^{-1}\right.$; Bentax 48, ANASAC, Santiago, Chile) was applied without flooding. The rice grain of all the genotypes was harvested in March with $20 \%$ moisture, and grain yield was evaluated with $14 \%$ adjusted moisture. No pesticide was applied because Chile is a pest-free country for rice production.

\section{Experimental design and statistical analysis}

The experimental design was a randomized complete block with three replicates. Three-way ANOVA was performed to determine the importance of genotype locations, seasons, and interactions in rice plant performance. Differences between genotype grain yields were analyzed by the LSD test $(\mathrm{P} \leq$ $0.05)$. Rice grain yield was also statistically analyzed with ANOVA under a mixed model with random genotype effect and fixed block effects. The genetic merit of each genotype was evaluated by BLUP using restricted maximum likelihood (REML) for variance component estimation (Searle et al., 1992). The GGE biplot methodology was used to analyze genotype performance for each environment, genotype stability, representative environment, and discriminating power of each environment.

The model for the GGE biplot was according to Yan and Hunt, 2002:

$$
y_{i j}-y_{j}=\lambda_{1} \xi_{i 1} \eta_{j 1}+\lambda_{2} \xi_{i 2} \eta_{j 2}+\varepsilon_{i j}
$$

where $y_{i j}$ is the mean grain yield of genotype $i$ in environment $j, y_{j}$ is the mean of genotypes in environment $j, \lambda_{1}$ and $\lambda_{2}$ are 
the eigenvalues for $\mathrm{PC} 1$ and $\mathrm{PC} 2, \xi_{i 1}$ and $\xi_{i 2}$ are the scores of genotype $i, \eta_{j 1}$ and $\eta_{j 2}$ are the scores for environment $j$, and $\varepsilon_{i j}$ is the residual term related to the mean of genotype $i$ in environment $j$.

All analyses were performed with the InfoStat statistical software and its interface with the lme4 package in $\mathrm{R}$ software (Di Rienzo et al., 2012).

\section{RESULTS AND DISCUSSION}

The main constraint to rice development is low temperatures; therefore, maximum, mean, and minimum temperatures were characterized for all the environments. Minimum temperatures were usually observed in October (near $5^{\circ} \mathrm{C}$ ) and maximum temperatures from December to January (near $30{ }^{\circ} \mathrm{C}$ ) (Figure 1). Similar temperatures were observed in the three evaluated locations. In the 2012-2013 season, mean and minimum temperatures in Chillán were lower than in the other locations during the rice cultivation period. Minimum temperatures in all seasons were below the minimum needed by the rice plant. The effects of cold on the crop depend on the growth stage, intensity, and exposure time (Díaz et al., 2006). Low temperatures can cause physiological alterations in rice (de Los Reyes et al., 2003; Aghaee et al., 2011); for example, reduced chlorophyll content (Aghaee et al., 2011), decreased photosynthetic activity (Allen and Ort, 2001; Díaz et al., 2006; Suzuki et al., 2008), and increased reactive oxygen species. Low temperatures during reproductive stages can decrease fertility, thus reducing rice grain yield (Shimono et al., 2002; Sato et al., 2011).

Differences between grain yield means were observed in genotypes evaluated in different environments (Table 2). The highest grain yield was determined for 'Quila 241319', which was $36 \%$ higher than the lowest grain yield genotype 'Buli-INIA'. High grain yield variation could be due to great differences in the genotypes. The highest grain yield values between cultivars was observed for 'Ámbar-INIA' in Parral in the 2010-2011 season and the lowest values were for 'Buli-INIA' in Chillán in the 2010-2011 season. Grain yield was higher in the 2011-2012 season than in the 2012-2013 season. The ANOVA results for rice grain yield are shown in Table 3. Genotype (G) was the principal source of variation and season (S) was the second. A low contribution to grain
Table 3. Three-way ANOVA analysis of rice trial yield performance.

\begin{tabular}{lrcr}
$\begin{array}{l}\text { Source of } \\
\text { variation }\end{array}$ & $\begin{array}{r}\text { Sum of } \\
\text { squares }\end{array}$ & $\begin{array}{c}\text { Mean } \\
\text { square }\end{array}$ & $\begin{array}{c}\text { Accounted } \\
(\%)\end{array}$ \\
\hline $\begin{array}{lrc}\text { Genotypes (G) } \\
\text { Location (L) }\end{array}$ & 16291.36 & $1810.15^{* * * *}$ & 28.8 \\
Season (S) & 650.78 & $325.39^{*}$ & 1.2 \\
$\mathrm{G} \times \mathrm{L}$ & 6686.21 & $3343.10^{* * *}$ & 11.8 \\
$\mathrm{G} \times \mathrm{S}$ & 1583.04 & 87.95 & 2.8 \\
$\mathrm{~L} \times \mathrm{S}$ & 2702.43 & 150.14 & 4.8 \\
$\mathrm{G} \times \mathrm{L} \times \mathrm{S}$ & 5945.41 & $1486.35^{* * *}$ & 10.5 \\
Error & 3170.97 & 88.08 & 5.6 \\
\hline $\mathrm{DF}: \mathrm{Degrees}$ & 17963.19 & 102.65 & 31.8 \\
\hline
\end{tabular}

DF: Degrees of freedom.

$*$, *** Significant at the 0.05 and 0.001 probability levels, respectively.

yield was observed for location (L) while a high contribution was determined for $\mathrm{L} \times \mathrm{S}$ interactions $(P>0.05)$. The low variation of grain yield between locations could be due to the small area under rice cultivation in Chile. The distance from Chillán to San Carlos, San Carlos to Parral, and Chillán to Parral are 21.2,36.6, and $56.9 \mathrm{~km}$, respectively. Temperatures were very similar between the different locations. Mean and minimum temperatures in Chillán were lower than the other locations only in the 2012-2013 season. Therefore, a low contribution of locations and $\mathrm{G} \times \mathrm{L}$ interaction are expected in grain yield variations observed in the present study. The study of grain yield using ANOVA and mixed models showed differences between genotypes across different environments (Figure 2). The experimental line 'Quila 241319' exhibited higher grain yield than other analyzed genotypes while grain yield of 'Buli-INIA' was the lowest. Chilean 'Cuarzo-INIA', 'Zafiro-INIA', and 'Diamante-INIA' were in the middle of the ranking.

A similar ranking was observed for grain yield analysis of genotypes using BLUPs. Three groups of genotypes with different grain yields were determined by this methodology. In the first group, 'Quila 242207', 'Ámbar-INIA', and 'Quila 241319' were considered as high grain yielding genotypes. 'Cuarzo-INIA', 'RQuila 17', 'Quila 208902', 'Diamante-INIA', and 'Zafiro-INIA' were middle grain yielding genotypes while 'Oro' and 'Buli-INIA' were low grain yielding genotypes. The BLUP values allow increasing the accuracy of the analysis to detect differences between genotypes in plant breeding (Piepho et al., 2008). The components of variance for grain yield evaluations at three

Table 2. Mean grain yield of evaluated rice genotypes across different environments.

\begin{tabular}{|c|c|c|c|c|c|c|c|c|c|}
\hline \multirow[b]{2}{*}{ Genotypes } & \multicolumn{3}{|c|}{ 2010-2011 } & \multicolumn{3}{|c|}{ 2011-2012 } & \multicolumn{3}{|c|}{ 2012-2013 } \\
\hline & Parral & San Carlos & Chillán & Parral & San Carlos & Chillán & Parral & San Carlos & Chillán \\
\hline & & & & & - $\mathrm{tha}^{-1}$ & & & & \\
\hline Ámbar-INIA & $9.8 \mathrm{a}-\mathrm{e}$ & $9.4 \mathrm{a}-\mathrm{e}$ & $11.8 \mathrm{a}-\mathrm{d}$ & $11.5 \mathrm{ab}$ & $10.8 \mathrm{a}$ & $11.8 \mathrm{a}-\mathrm{e}$ & $9.8 \mathrm{~b}-\mathrm{e}$ & $10.2 b-f$ & $9.4 \mathrm{~b}-\mathrm{e}$ \\
\hline Buli-INIA & $7.7 \mathrm{e}-\mathrm{g}$ & $6.8 f-g$ & $8.2 \mathrm{~g}$ & $9.3 \mathrm{fg}$ & $9.4 \mathrm{fg}$ & $8.9 \mathrm{cg}$ & 8.0ij & $8.8 \mathrm{~h}-\mathrm{j}$ & $7.9 \mathrm{f}-\mathrm{j}$ \\
\hline Cuarzo-INIA & $8.8 \mathrm{~b}-\mathrm{g}$ & $8.3 b-g$ & $9.1 \mathrm{e}-\mathrm{g}$ & $10.3 \mathrm{~b}-\mathrm{g}$ & $9.7 \mathrm{~b}-\mathrm{g}$ & $10.0 \mathrm{c}-\mathrm{g}$ & $8.5 \mathrm{f}-\mathrm{j}$ & $9.0 \mathrm{~b}-\mathrm{g}$ & $9.2 \mathrm{e}-\mathrm{j}$ \\
\hline Diamante-INIA & $9.0 \mathrm{~b}-\mathrm{g}$ & $7.5 \mathrm{~d}-\mathrm{g}$ & $9.3 \mathrm{~d}-\mathrm{g}$ & $10.4 \mathrm{~b}-\mathrm{g}$ & $9.9 b-g$ & $9.9 b-g$ & $9.2 c-i$ & $9.4 \mathrm{a}-\mathrm{c}$ & $10.0 \mathrm{~d}-\mathrm{i}$ \\
\hline Oro & $8.7 b-g$ & $8.4 \mathrm{~b}-\mathrm{g}$ & $9.5 \mathrm{c}-\mathrm{g}$ & $10.6 b-f$ & $8.8 \mathrm{~b}-\mathrm{g}$ & $9.6 \mathrm{~g}$ & $8.9 \mathrm{~d}-\mathrm{j}$ & $8.7 \mathrm{j}$ & $7.4 \mathrm{~g}-\mathrm{j}$ \\
\hline Quila 208902 & $7.9 \mathrm{~d}-\mathrm{g}$ & $7.6 \mathrm{c}-\mathrm{g}$ & $10.6 a-g$ & $10.4 \mathrm{~b}-\mathrm{g}$ & $10.2 b-g$ & $9.9 \mathrm{~b}-\mathrm{g}$ & $9.3 \mathrm{c}-\mathrm{h}$ & $9.6 \mathrm{~d}-\mathrm{i}$ & $8.7 \mathrm{c}-\mathrm{h}$ \\
\hline Quila 241319 & $10.6 \mathrm{a}-\mathrm{c}$ & $10.2 \mathrm{ab}$ & $13.0 \mathrm{a}$ & $12.5 \mathrm{a}$ & $12.2 \mathrm{a}-\mathrm{c}$ & $10.7 \mathrm{a}$ & $10.7 \mathrm{ab}$ & $11.7 b-d$ & $9.7 \mathrm{a}$ \\
\hline Quila 242207 & $9.4 \mathrm{a}-\mathrm{f}$ & $8.6 b-g$ & $10.0 \mathrm{~b}-\mathrm{g}$ & $11.0 \mathrm{a}-\mathrm{e}$ & $12.1 \mathrm{a}-\mathrm{d}$ & $10.6 \mathrm{a}$ & $9.5 b-g$ & $9.9 \mathrm{~d}-\mathrm{j}$ & $8.6 \mathrm{~b}-\mathrm{g}$ \\
\hline RQuila 17 & $8.7 \mathrm{~b}-\mathrm{g}$ & $7.7 \mathrm{c}-\mathrm{g}$ & $9.7 b-g$ & $9.4 \mathrm{e}-\mathrm{g}$ & $9.5 \mathrm{c}-\mathrm{g}$ & $9.5 \mathrm{c}-\mathrm{g}$ & $10.0 \mathrm{~b}-\mathrm{d}$ & $9.7 b-d$ & $9.7 \mathrm{c}-\mathrm{h}$ \\
\hline Zafiro-INIA & $7.8 \mathrm{e}-\mathrm{g}$ & $8.7 \mathrm{a}-\mathrm{g}$ & $11.0 \mathrm{a}-\mathrm{f}$ & $9.5 \mathrm{~d}-\mathrm{g}$ & $10.2 b-g$ & $9.8 \mathrm{~b}-\mathrm{g}$ & $9.7 b-g$ & $9.5 b-d$ & $9.7 \mathrm{c}-\mathrm{i}$ \\
\hline
\end{tabular}

Values with different letters differ one from the other (LSD test, $\mathrm{P}<0.05$ ) within the season. 
Figure 2. Ranking of rice genotypes during three seasons at three locations.

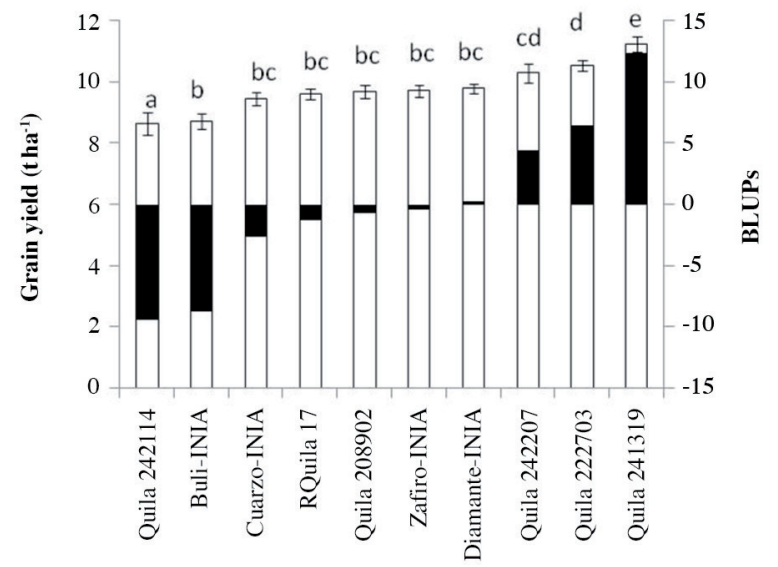

White bars represent grain yield and black bars represent the best linear unbiased predictor (BLUP) values for grain yield. The error bar is the standard error of three replicates and different letters indicate significant differences between genotypes according to Fisher's LSD test $(\mathrm{P}<0.05)$.

locations for three years were estimated by a mixed model (Table 4). The results were similar to the ANOVA analysis. The genotype was the most important variation source $(25 \%)$.

Table 4. Components of variance for grain yield of rice genotypes assessed in different environments using mixed models.

\begin{tabular}{lrc}
\hline Source of variation & $\sigma^{2}$ & Accounted (\%) \\
\hline Genotype (G) & 60.5 & 25.5 \\
Location (L) & 7.8 & 3.3 \\
Season (S) & 20.6 & 8.7 \\
G $\times$ L & 0.0 & 0.0 \\
G $\times$ S & 6.4 & 2.7 \\
L $\times$ S & 43.3 & 18.2 \\
G $\times$ L $\times$ S & 0.0 & 0.0 \\
Error & 98.8 & 41.6 \\
\hline
\end{tabular}

$\sigma^{2}$ : Variance.
The importance of the season $(8.7 \%)$ was intermediate, the significance for location was low, and a high $\mathrm{G} \times \mathrm{S}$ interaction was observed. The important contribution of genotype and a low contribution for location can be explained by the small size of the Chilean rice zone. The principal contribution of genotype in the variance demonstrated the possibility of improving grain yield by using new experimental lines. However, the importance of the season in the analysis involves some constraints to generate new cultivars. The challenges of the breeding program should therefore be focused on the different seasons instead of in changes related to rice locations. High grain yield variability was observed in PC1, which explained $74.3 \%$ of the total variation (Figure 3 ). All seasons and locations were positively correlated. It was possible to identify one principal mega-environment and three high grain yielding genotypes by GGE biplot analysis. In this environment, only three genotypes were found, that is, 'Quila 242207', 'Ámbar-INIA', and the highest grain yield 'Quila 241319'. The high contribution of genotype to the variance component was not observed in other studies related to rice. Published rice multi-environment studies generally show a high contribution of environment or $\mathrm{G} \times \mathrm{E}$ interaction (> 26\%) (Samonte et al., 2005; Camargo-Buitrago et al., 2011). The explanation could be related to low variance in climate due to the small rice area. Most environments were located in one mega-environment. Only one environment (Chillán, 2012-2013) was observed in another mega-environment, which could be due to the difference in temperatures in Chillán for the 2012-2013 season with a minimum close to $5{ }^{\circ} \mathrm{C}$, which is lower than other locations and seasons. The mean performance and stability of rice genotypes were analyzed by an average environment coordination method (Yan and Hunt, 2002). A high correlation between genotype yields and PC1 scores for genotypes $(r=0.99)$ support the

Figure 3. GGE Biplot grain yield of rice genotypes in different environments.

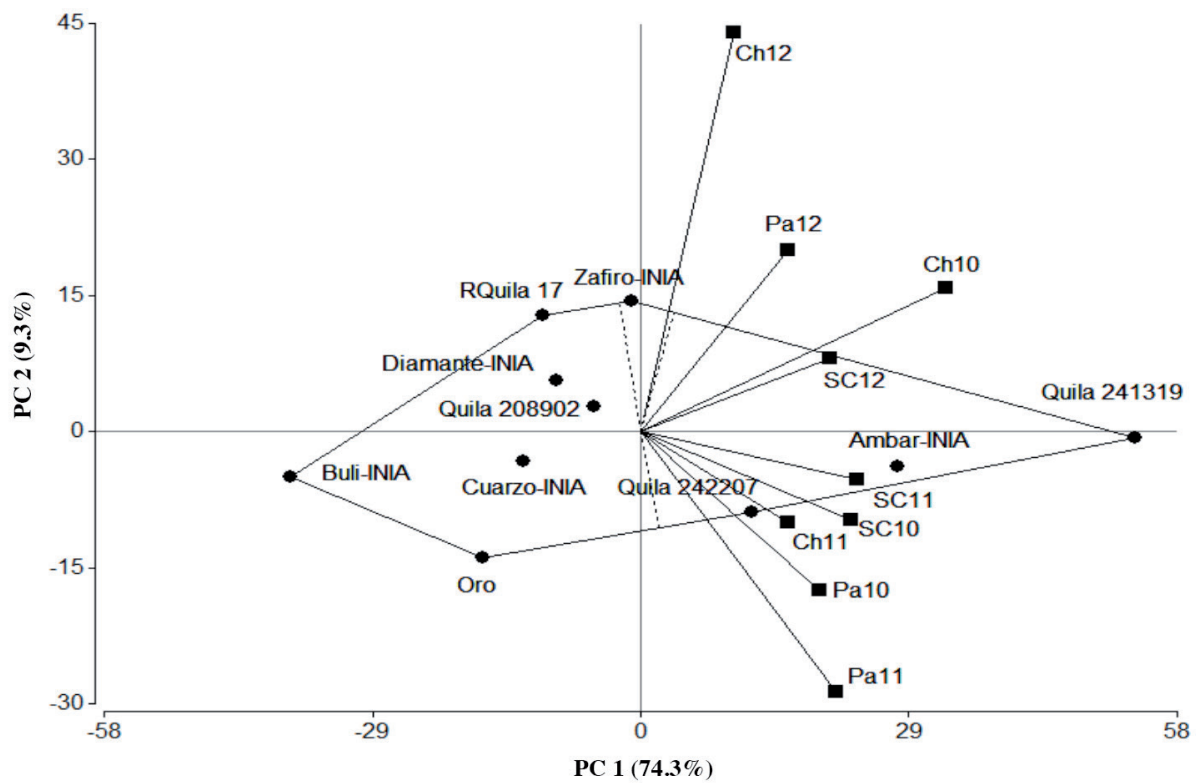

A dotted line represents the division of mega-environments, black squares are nine environments, and black circles are genotypes. Ch10, Ch11, and Ch12 are Chillán in the 2010-2011, 2011-2012, and 2012-2013 seasons, respectively. SC10, SC11, and SC12 are San Carlos in the 2010-2011, 2011-2012, and 20122013 seasons, respectively. Pa10, Pa11, and Pa12 are Parral in the 2010-2011, 2011-2012, and 2012-2013 seasons, respectively. 
Figure 4. GGE biplot to analyze performance and stability of rice genotype grain yield.

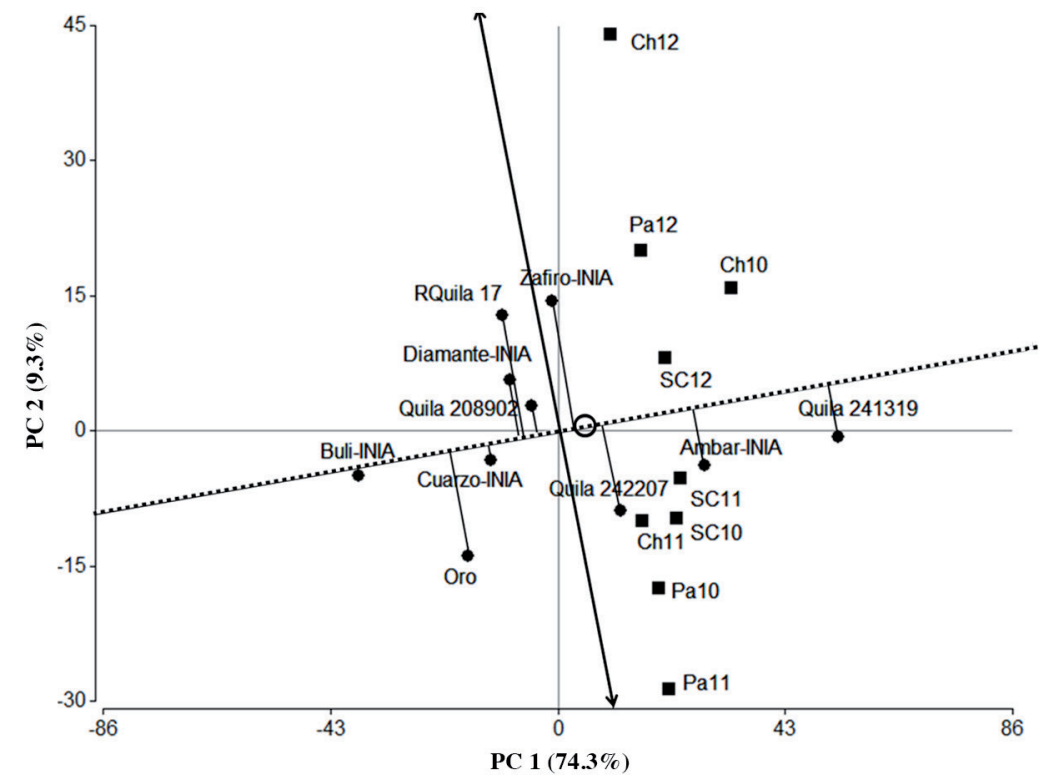

Black squares are the nine environments and black circles are genotypes. The open circle represents the average environment. The dotted line is the mean yield across environments. The double-arrowed line is poor stability in either direction. The length of the black line that connects the genotype with the dotted line is the instability of each genotype. Ch10, Ch11, and Ch12 is Chillán in the 2010-2011, 2011-2012, and 2012-2013 seasons, respectively. SC10, SC11, and SC12 is San Carlos in the 2010-2011, 2011-2012, and 2012-2013 seasons, respectively. Pa10, Pa11, and Pa12 is Parral in the 2010-2011, 2011-2012, and 2012-2013 seasons, respectively.

use of GGE biplot to identify the ideal genotype. The mean grain yield of 'Quila 241319' was the highest and 'BuliINIA' was the lowest. The stability of 'Buli-INIA', 'CuarzoINIA', and 'Quila 2080902' were the highest whereas the lowest stability was observed in 'Zafiro-INIA', 'RQuila17', 'Oro', and 'Quila 242207'. 'Ámbar-INIA', 'Quila 241319', and 'Diamante-INIA' exhibited intermediate stability. After the evaluations, 'Quila 241319' was considered as the ideal genotype. The most representative environment corresponds to location and season with a low value (absolute) in PC2, and the environment with high power to discriminate corresponds to locations and seasons with high values in PC2 (Figure 4). San Carlos (SC10, SC11, and SC12) was considered as the best representative location with the power to discriminate. Only Chillán was higher in the power to discriminate genotypes than San Carlos in 2010. These evaluations are useful for choosing locations and genotype selection in a breeding program.

\section{CONCLUSIONS}

Grain yield analysis using ANOVA, mixed models based on BLUPs, and genotype plus Genotype $\times$ Environment interaction (GGE) allowed us to find the best performance genotype, 'Quila 241319', one principal mega-environment, and San Carlos as the ideal environment to study rice grain yield.

\section{ACKNOWLEDGEMENTS}

The authors would like to thank the Fondo de Fomento al Desarrollo Científico y Tecnológico (FONDEF), grant $\mathrm{N}^{\circ}$
D10I1183, for supporting this research. We are also thankful to Fernando Saavedra B. for his technical assistance.

\section{REFERENCES}

Aghaee, A., F. Moradi, H. Zare-Maivan, F. Zarinkamar, H. Pour Irandoost, and P. Sharifi. 2011. Physiological responses of two rice (Oryza sativa L.) genotypes to chilling stress at seedling stage. African Journal of Biotechnology 10:7617-7621.

Akter, A., M. Jamil Hassan, M. Umma Kulsum, M.R. Islam, K. Hossain, and M. Mamunur Rahman. 2014. AMMI biplot analysis for stability of grain yield in hybrid rice (Oryza sativa L.) Rice Research 2:126.

Allen, D.J., and D.R. Ort. 2001. Impacts of chilling temperatures on photosynthesis in warm-climate plants. Trends in Plant Science 6:36-42.

Alvarado, R., y S. Hernaiz. 2007. Antecedentes generales sobre el arroz en Chile. In Alvarado, R. (ed.) Arroz. Manejo tecnológico. Boletín INIA $\mathrm{N}^{\circ} 162.179$ p. Instituto de Investigaciones Agropecuarias INIA, Centro Regional de Investigación Quilamapu, Chillán, Chile.

Bose, L.K., N.N. Jambhulkar, K. Pande, and O.N. Singh. 2013. Use of AMMI and other stability statistics in the simultaneous selection of rice genotypes for yield and stability under direct-seeded conditions. Chilean Journal of Agricultural Research 74:3-9.

Camargo-Buitrago, I., E. Quirós-McIntire, y R. Gordón-Mendoza. 2011. Identificación de mega-ambientes para potenciar el uso de genotipos superiores de arroz en Panamá. Pesquisa Agropecuária Brasileira 46:1061-1069.

Cantrell, R.P., and T.G. Reeves. 2002. The rice genome: The cereal of the World's poor takes center stage. Science 296:53.

Colombari Filho, J.M., M.D.V. de Resende, O.P. de Morais, A. Pereira, E.P. Guimarães, J.A. Pereira, et al. 2013. Upland rice breeding in Brazil: a simultaneous genotypic evaluation of stability, adaptability and grain yield. Euphytica 192:117-129. 
de Los Reyes, B.G., M. Morsy, J. Gibbons, T.S.N. Varma, W. Antoine, J.M. McGrath, et al. 2003. A snapshot of the low temperature stress transcriptome of developing rice seedling (Oryza sativa L.) via ESTs from subtracted cDNA library. Theoretical and Applied Genetics 107:1071-1082.

Di Rienzo, J.A., F. Casanoves, M.G. Balzarini, L. Gonzalez, M. Tablada, y C.W. Robledo. InfoStat versión. 2012. Grupo InfoStat, FCA, Universidad Nacional de Córdoba, Argentina. URL http:// www.infostat.com.ar.

Díaz, S., R. Morejón, R. Castro, y N. Pérez. 2006. Comportamiento de genotipos de arroz (Oryza sativa L.) seleccionados para tolerancia a bajas temperaturas en siembra temprana de frío. Cultivos Tropicales 27: 71-75.

Donoso, G., M. Leyton, M. Paredes, and V. Becerra. 2014. Relative expression of genes related with cold tolerance in temperate rice at the seedling stage. African Journal of Biotechnology 13:2506-2512.

Heffner, E.L., M.E. Sorrells, and J.-L. Jannink. 2009. Genomic selection for crop improvement. Crop Science 49:1-12.

Hirzel, J., A. Pedreros, and K. Cordero. 2011. Effect of nitrogen rates and split nitrogen fertilization on grain yield and its components in flooded rice. Chilean Journal of Agricultural Research 71:437-444.

Karimizadeh, R., M. Mohammadi, N. Sabaghni, A.A. Mahmoodi, B. Roustami, F. Seyyedi, et al. 2013. GGE biplot analysis of yield stability in multi-environment trials of lentil genotypes under rainfed condition. Notulae Scientia Biologicae 5:256-262.

Khush, G.S. 1997. Origin, dispersal, cultivation and variation of rice. Plant Molecular Biology 35:25-34.

Khush, G.S. 2005. What it will take to Feed 5.0 Billion Rice consumers in 2030. Plant Molecular Biology 59:1-6.

ODEPA. 2013. Mercado del arroz: crecimiento en el mundo y cambios productivos en Chile. Oficina de Estudios y Políticas Agrarias (ODEPA), Santiago, Chile. Available at http://www. odepa.cl/wp-content/files_mf/138211656712609.pdf (accessed April 2015).
ODEPA. 2015. Boletín del arroz. Oficina de Estudios y Políticas Agrarias (ODEPA). Available at http://www.odepa.cl/wpcontent/files_mf/1429215785Boletíndelarroz201504.pdf (accessed April 2015).

Piepho, H.P., J. Möhring, A.E. Melchinger, and A. Büchse. 2008. BLUP for phenotypic selection in plant breeding and variety testing. Euphytica 161:209-228.

Samonte, S.O.P.B., L.T. Wilson, A.M. McClung, and J.C. Medley. 2005. Targeting cultivars onto rice growing environments using AMMI and SREG GGE biplot analysis. Crop Science 45:2414-2424.

Sanghera, G.S., S.H. Wani, W. Hussain, and N.B. Singh. 2011. Engineering cold stress tolerance in crop plants. Current Genomics 12:30-43.

Sato, Y., Y. Masuta, K. Saito, S. Murayama, and K. Ozawa. 2011. Enhanced chilling tolerance at the booting stage in rice by transgenic overexpression of the ascorbate peroxidase gene, OsAPXa. Plant Cell Reports 30:399-406.

Searle, S.R., G. Casella, and C.E. McCulloch. 1992. Variance components. 528 p. J. Wiley, New York, USA.

Shimono, H., T. Hasegawa, and K. Iwama. 2002. Response of growth and grain yield in paddy rice to cool water at different growth stages. Field Crops Research 73(2-3):67-79.

Suzuki, K., K. Nagasuga, and M. Okada. 2008. The chilling injury induced by high root temperature in the leaves of rice seedlings. Plant and Cell Physiology 49:433-442.

Yan, W., and L.A. Hunt. 2002. Biplot analysis of diallel data. Crop Science 42:21-30.

Zhang, Q., Q. Chen, S. Wang, Y. Hong, and Z. Wang. 2014. Rice and cold stress: methods for its evaluation and summary of cold tolerance-related quantitative trait loci. Rice 7:24. 